\title{
Physio-chemical and Microstructural Characteristics of Selected Pozzolanic Materials for Cement and Concrete Production
}

\author{
D. O. Oyejobi ${ }^{1 *}$, S. A. Raji ${ }^{1}$, S. T. Aina ${ }^{1}$, A. Siva ${ }^{2}$ \\ ${ }^{1}$ Department of Civil Engineering, University of Ilorin, Ilorin, Nigeria. \\ ${ }^{2}$ Department of Civil Engineering, Vaagdevi College of Engineering, Warangal, India.
}

\begin{abstract}
Abundant aquatic animal by-products are available in Nigeria which include clam, oyster, rock Snail and periwinkle shells. These are usually dumped on open lands without any economic value after fleshy parts of these animals had been consumed by humans, hence, result into environmental problems. In the agricultural sector, Rice husk and Palm oil fuel ashes are by-products from rice and palm oil industries after the husks have been used as source of fuel. Disposal of these wastes are always a major issue as they constitute nuisance to the environment. This research has collected and characterized these wastes in the laboratory to ascertain their suitability as supplementary cementitious materials. With this study, physical properties such as particle size, specific gravity, specific surface area and morphology are conducted by Scanning Electron Morphology, SEM; chemical analysis are carried out with the aid of X-ray Fluorescence (XRF), for microstructure examination, X-ray Diffraction (XRD) machine is used for detecting minerals in the materials while Field Emission Scanning Electron Microscopy and Energy-Dispersive X-ray analysis (FESEM-EDX) are used for image and element detection. The results of these analyses will help in the future work of pozzolanic and geopolymer construction in Nigeria. The results are further compared with previous literature to see their compatibility and discrepancy.
\end{abstract}

KEYWORDS: Aquatic, agricultural, cementitious, SEM, XRF, XRD, FESEM-EDX

\section{INTRODUCTION}

Out of thirty-six States in Nigeria, coastline runs through seven States of the federation which are Lagos, Ondo, Delta, Bayelsa, Rivers, Akwa-Ibom and Cross Rivers as shown in Figure 1. These states house abundant marine animals and after the consumption of the fleshy parts, their shells are left all over the lands without any appreciable re-use. This act does not only occupy useful lands but also cause pollution which is detrimental to a healthy environment. Previously, oil palm plantation had thrived as a commercial source of income in Nigeria. This boom business was lost to Malaysia and Indonesia, (PIND) (2011) due to the discovery of crude oil in the mid 50's. However, much effort has been geared by the government at various levels in reviving the sector and a lot of plantations are now thriving well which undoubtedly produce a huge amount of waste products which could be harvested and channelled to our gain such as fuel for energy efficiency as well as partial and full replacement of Portland cement.

On the other hand, rice is cultivated in almost all the thirtysix states of Nigeria, although predominantly abundant in the North central part of the country and is a major source of food with the rice husk left as a waste. Periwinkle shells had been previously included as aggregates in the concrete works as reported in the article of Umoh and Olusola (2013). To the best of our knowledge, the use of clams, oyster, periwinkle and *Corresponding author: damilolaoyejobi@gmail.com snail shell either for partial or full replacement of cement in the concrete production in Nigeria is still at the developing stage. Globally, some waste materials have been characterized and implemented for geopolymer concrete. These include, ground granulated blast furnace slag, palm oil clinker powder, and rice husk ash. Others are fly ash, bottom ash, palm oil fuel ash, silica fume etc. Hence, the aim of this study is to characterize suitability of these ashes for the inclusion in the geopolymer paste, mortar and concrete.

The objectives of this research include determination of the elements, percentage of chemical oxides and minerals in each identified shell, morphology of the shells and micro-structural arrangement of the shells. The highlighted objectives are key parameters which aid in determining whether the shells can be adopted for geopolymer applications and their likely properties of the concrete based on the material make-up. Investigators such as Bakar, Putrajaya, and Abdulaziz (2010) and Aprianti, Shafigh, Bahri, and Farahani (2015) reported RHA to be grey in colour while Foong, Alengaram, Jumaat, and Mo (2015) and Hassan Noorvand, Abang Ali, Demirboga, Farzadnia, and Noorvand (2013) reported a black colour.

The difference in observed colour could be as a result of different incineration condition. Specific gravity result from all reviewed works is in the range of 1.94-3.68. M. Karim, M. F. M. Zain, M. Jamil, and F. Lai (2013) recorded a specific doi: http://dx.doi.org/10.4314/njtd.v16i3.4 
surface area of $1.27 \mathrm{~m}^{2} / \mathrm{g}$, M. Jamil, M. Khan, M. Karim, A. Kaish, and M. Zain (2016) $1.67 \mathrm{~m}^{2} / \mathrm{g}$ while Givi, Rashid, Aziz, and Salleh (2010) recorded $2.44 \mathrm{~m}^{2} / \mathrm{g}$. Basha, Hashim, Mahmud, and Muntohar (2005), Foong et al. (2015), and Rahman, Muntohar, Pakrashi, Nagaratnam, and Sujan (2014) reported that RHA has an average particle size of $45 \mu \mathrm{m}, 20$ $\mu \mathrm{m}$ and $75 \mu \mathrm{m}$ respectively. These levels of fineness affect reactivity of the binder with aggregates and strength development as well.

The basic physical properties of rice husk ash, RHA as stated by Ayininuola and Olaosebikan (2013) are specific gravity and bulk density with specific gravity of RHA varying with the calcination temperature. It was reported to decrease from 2.00 at $400^{\circ} \mathrm{C}$ to 1.05 at $800^{\circ} \mathrm{C}$, [08]. (Ogork and Uche (2014)), Ettu, Ajoku, Nwachukwu, Awodiji, and Eziefula (2013) reported the bulk density of RHA as $368.50 \mathrm{~kg} / \mathrm{m}^{3}$. [16] examined RHA to have bulk density of $770 \mathrm{Kg} / \mathrm{m}^{3}$, specific gravity of 1.85 , and fineness modulus of 1.45 without special treatment or milling of the ash. Tsado, Yewa, Yaman, and Yewa (2014) stated that workability of concrete decreases with increase in the percentage replacement of RHA. The setting times of mortars made from partially replacing cement for all calcination temperatures of RHA are higher than those of OPC mortars, Basha et al. (2005).

Abalaka (2013) reported a Loss on Ignition, (LOI), a measure of the quantity of unburnt carbon in the RHA as $0.77 \%$ at $800^{\circ} \mathrm{C}$ (6 minutes) and $3.88 \%$ at $1050^{\circ} \mathrm{C}$ ( 3 hours) which satisfied the Astm (2003b) values of the LOI requiring maximum of $6 \%$ for pozzolans used in concrete. As stated in the same work, milled RHA had a low specific surface area of $235 \mathrm{~m}^{2} / \mathrm{kg}$ with fifty percent of the RHA particles less than $46.451 \mu \mathrm{m}$ in diameter and ninety percent of the particles less than $178.521 \mu \mathrm{m}$ using laser diffraction technique. The chemical analysis on RHA at about $700^{\circ} \mathrm{C}$ using a controlled blast furnace for four hours and milled to obtain a finely divided ash revealed a Silica, Alumina, Iron oxide, and Calcium oxide content of $77.267 \%, 3.592 \%, 9.846 \%$ and $8.947 \%$ respectively. The percentage composition of $\mathrm{SiO}_{2}$, $\mathrm{Al}_{2} \mathrm{O}_{3}$ and $\mathrm{Fe}_{2} \mathrm{O}_{3}$ summed up to $90.71 \%$ satisfying Astm (2003b) minimum requirements for pozzolanas. Study of Strength variation of OPC-RHA composites as carried out by Ettu et al. (2013) and Agbenyeku and Aneke (2014) reported that the RHA satisfied ASTM requirement that the sum of $\mathrm{SiO}_{2}, \mathrm{Al}_{2} \mathrm{O}_{3}$, and $\mathrm{Fe}_{2} \mathrm{O}_{3}$ should be not less than $70 \%$ for pozzolans.

Palm Oil Fuel Ash (POFA) is one of the by-products from the palm oil mill industry whose recycling potential is yet to be fully exploited, Okafor and Okonkwo (2009). Palm oil is produced generally in most of the Eastern, Western and Southern parts of Nigeria, a total of about 930 metric ton of palm oil at a growth rate of $2.20 \%$ per annum is produced in Nigeria as reported by Opeyemi and Makinde (2012). As noticed, Palm oil is consumed in almost all the households in Nigeria on a daily basis leaving behind large amount of residues like fibers, nutshells and empty fruit bunches. These residues are burnt at $800-1000^{\circ} \mathrm{C}$, to produce heat for steam generation in palm oil mills. Large volumes of POFA are annually disposed of in landfills as waste.
Specifically, POFA has been found to possess pozzolanic properties, as it contains a large amount of $\mathrm{SiO}_{2}$. From the studies conducted by Siddique, Aggarwal, and Aggarwal (2012), Singh and Siddique (2014), Slavik, Bednarik, Vondruska, and Nemec (2008), Bai, Darcy, and Basheer (2005), Hanjitsuwan, Phoo-ngernkham, and Damrongwiriyanupap (2017), Lin, Chang, and Lin (2008), Pyo and Kim (2017), Marto, Kassim, Makhtar, Wei, and Lim (2010), S Naganathan, Subramaniam, and Mustapha (2012), Sivakumar Naganathan, Mohamed, and Mustapha (2015), POFA has high $\mathrm{SiO}_{2}(>60 \%)$ content, low $\mathrm{Al}_{2} \mathrm{O}_{3}(<8.0 \%)$ content, and high $\mathrm{P}_{2} \mathrm{O}_{5}(3.78 \%-4.69 \%)$ content compared to class $\mathrm{C}$ and class $\mathrm{F}$ fly ash, GGBFS, and MK or calcined kaolin. In the same vein, compared to GGBFS, and MK or calcined kaolin, POFA has higher $\mathrm{Fe}_{2} \mathrm{O}_{3}$ content while compared to class $\mathrm{F}$ fly ash and $\mathrm{MK}$, it has higher $\mathrm{MgO}$ and $\mathrm{CaO}$ content. This good combination makes the POFA to possess both pozzolanic and cementitious properties as there is even distribution of oxides that makes is closer to ordinary Portland cement.

The POFA powder XRD primarily exhibited composition of crystalline phases of quartz and mullite. Only a few small peaks could be identified as crystalline silica in Ranjbar, Mehrali, Behnia, Alengaram, and Jumaat (2014).

On the other hand, Olivia and Oktaviani (2017) partially replaced cement at $4 \%$ with cockle and marsh clams. It is reported that mechanical properties of cockle clam mixed with OPC are lower than the control mix of OPC while marsh clam type yielded increased mechanical properties. The differences are attributed to different calcium oxides in each of the clam. Lertwattanaruk, Makul, and Siripattarapravat (2012) utilized four types of clams with a cement replacement ranging between 5 to $20 \%$ by weight. It is discovered that there was a result of adequate strength, water requirement and increased in setting times of the mortars, although increase in the percentage of clam shells reduced the compressive strength due to the less reactivity.

Umoh and Olusola (2013) studied performance of portland-pozzolan cement in acidic medium with a mixture of OPC and Periwinkle shell ash with a ratio between 10 to $40 \%$ by volume. Increase in the percentage of periwinkle shell ash increases water requirement. Compressive strength increases with casting age but decreases with percentage increase in periwinkle shell ash due to the higher water content. However, loss in compressive strength in $\mathrm{MgSO}_{4}$ solution is reduced for Portland-pozzolan compared to percentage in the OPC mix. Barbachi, Imad, Jeffali, Boudjellal, and Bouabaz (2017) characterized crushed mussel shells for their possibility use in the concrete. Muthusamy and Sabri (2012) replaced coarse aggregates with cockle shell up to $30 \%$ with $20 \%$ replacement giving best workability and compressive strength results. Rough shape of the shell has attributed to the low workability but also improved bonding and hence compressive strength of the concrete.

Ponnada, Prasad, and Dharmala (2016) substituted both fine and coarse aggregates with granite powder and cockle shells with the maximum compressive strength of $43.7 \mathrm{MPa}$ for $20 \%$ and $15 \%$ of granite powder and cockle shells. Othman, Bakar, Don, and Johari (2013) used cockle shell ash to replace 
cement between the amount of 5 to $50 \%$ with decrease in compressive as the percentage increases. High content of Calcium oxide causes slow hydration process. Importantly, permeability and porosity of the concrete with cockle shell ash reduced compared to the control mix.

\section{MATERIALS AND METHODS}

\section{A. Materials}

The following sections explain the abundant local materials and the methods used for the characterization of the byproducts from the agricultural and marine sectors. Four marine shells were collected from Port-Harcourt, eastern part of the Country, Nigeria with the location as shown in Fig.1. By their nomenclatures, these are known to be Clam, Periwinkle, Oyster and Rock Snails Shells. Rice husk and Palm Oil Kernel Shells are collected from the milling factories in Ilorin, Kwara State, Nigeria. Their respective pictures are shown in Fig. 2. Their calcinations were carried out using Carbolite furnace at a temperature of $700^{\circ} \mathrm{C}$ for a period of four hours.

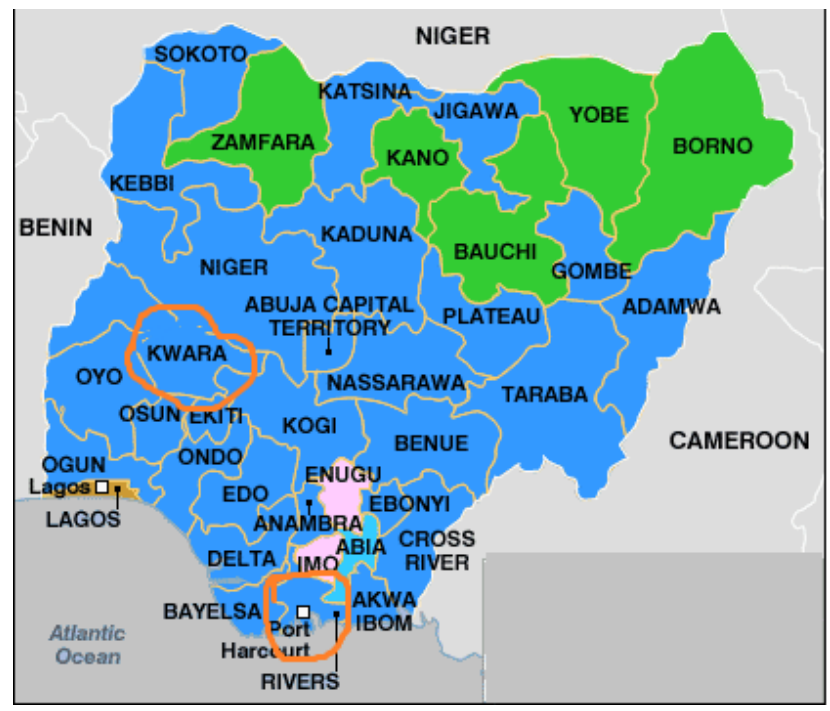

Figure 1: Study Map of Nigeria highlighting Port-Harcourt and Kwara.

\section{B. Methods for characterization of the materials}

The following sub-sections explained methods undertaken in carrying out physical, chemical and mineral compositions of the ashes following the standard codes and procedures.

\section{Physical properties}

The morphology analysis of the ashes was carried out with the help of Phenom table top Scanning Electron Morphology (SEM) that has acceleration between 5 to $15 \mathrm{kV}$. Particle size

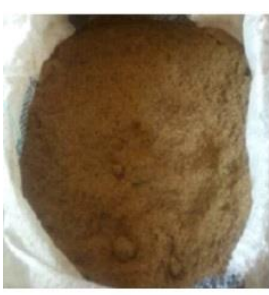

a. Rice husk

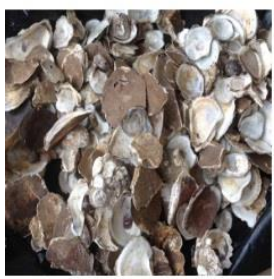

d. Oyster shells

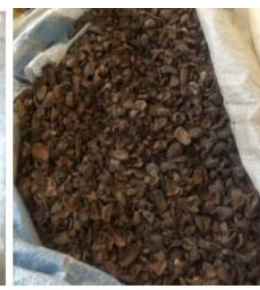

b. Palm kernel shells c. Clam shells

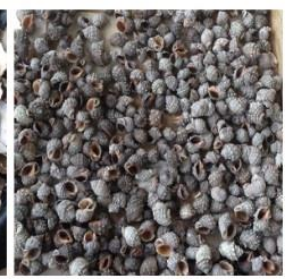

e. Rock snail
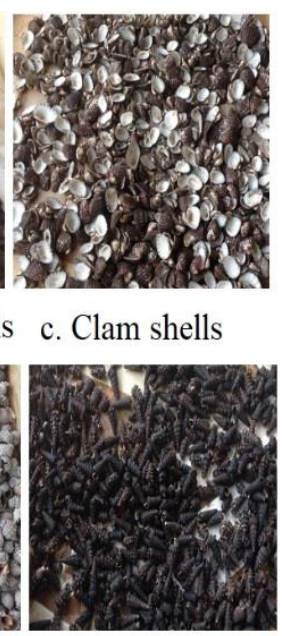

f. Periwinkle shells
Figure 2: Pictographs of the agro-industrial wastes.

analyzer is used for determination of volume of materials for each sieve size with their distribution. From the Figure 2, the colour of the ashes was observed for each waste material, which was followed by the determination of Blaine specific surface area.

\section{Chemical characterization}

The oxides and elements in each ash and powder are determined using the X-ray fluorescence (XRF) spectrometer by PANalytical which is suitable for elemental and thin film analysis, and by FESEM-EDX. The X-ray fluorescence (XRF) spectrometer is installed with innovative elemental excitation capable of identifying main and trace chemical oxides.

\section{E. Mineral composition}

XRD diffractometer system with the name EMPYREAN was used to determine the mineral composition in the ashes with the standard measurement of slow scan type. The Start and End Position of 2 deg theta are 5.0129 and 79.9709 with the Step Size of 0.0260 and Scan Step Time (s) of 148.9200. Other details of the diffractometer are anode material of $\mathrm{Cu}, \mathrm{K}$

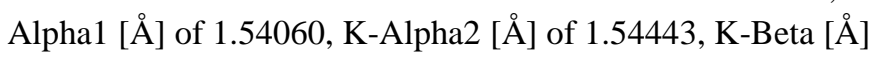
of 1.39225 and K-A2 / K-A1 Ratio of 0.50000. Specimen length is $10.00 \mathrm{~mm}$ with the measurement temperature of $25^{\circ} \mathrm{C}$.

\section{RESULTS AND DISCUSSION}

The analysis results from each characterization are carried out and reported in the following sub-sections. 
A. Visual properties of the agro-marine waste products

In Figure 2, various pictures of the raw materials utilized in this study are shown, starting with rice husk to periwinkle shells. This class of biomass is from both crops and marine animals which is continuously and abundantly available. The colour of these waste materials depends upon the species of the materials and their respective source of origin. These materials are all pretreated by removing dirt, other possible contaminants and grounded into the powder forms. As at today and to the best of knowledge of the authors, none of these materials have been fully incorporated at a commercial scale either for fuelling or partial replacement for a sustainable housing in Nigeria.

\section{B. Particle size distribution of the ashes and powders}

Fineness of the grounded ashes is determined based on the limits set in ASTM C618 (2003) for coal and other natural pozzolan for use in concrete. The maximum limit of the sample to be retained on sieve No $45 \mu \mathrm{m}$ is $34 \%$. From the Table 1 , all the ashes are below the limit except POFA which is slightly above the limit. This can be adjusted by re-grinding in the ball mill. The finer sea-shell powders will aid easy hydration and strength development in the concrete when used in the concrete, this claim had earlier been reported by Zain, Islam, Mahmud, and Jamil (2011) and Hesami, Ahmadi, and Nematzadeh (2014) that fineness affects rate of reaction, gain of strength, workability, creep, slump and shrinkage.

Depending on the grinding time and method, Aprianti et al. (2015) reported average diameter is between $16.6 \mu \mathrm{m}$ to 49 $\mu \mathrm{m}$, in which the present study average diameter is $6.02 \mu \mathrm{m}$ to $26.8 \mu \mathrm{m}$ for all the samples. After 12 hours of POFA grinding by Salih, Farzadnia, Abang Ali, and Demirboga (2015), the SSA value was $0.915 \mathrm{~m}^{2} / \mathrm{g}$. Other parameters as reported in the Table 1 are specific surface area, the higher the SSA, the finer the material will be and this will improve strength development, Chindaprasirt and Rukzon (2008). The average size recorded by Lertwattanaruk et al. (2012) for Portland cement, short-necked clam, oyster and cockle are 22.82, 20.80, 13.93 and $13.56 \mu \mathrm{m}$ respectively which when compared with the present study as tabulated in Table 1, the results of the present study were found to have lower mean value except for POFA.

The LOI is meant as an indicator of the amount of un-burnt carbon in incinerated products. Thermal decomposition was what has simply occurred on marine by-products, having not been previously incinerated like the other pozzolans, hence the LOI values exceeded the limit set out by the standard.

Table 1: Properties from particle size distribution analysis.

\begin{tabular}{lllllll}
\hline Parameters & RHA & POFA & CLAM & OYSTER & $\begin{array}{l}\text { ROCK } \\
\text { SNAIL }\end{array}$ & $\begin{array}{l}\text { PERI } \\
\text { WINKLE }\end{array}$ \\
\hline LOI & 7 & 4.83 & 43 & 43.5 & 44.20 & 6.02 \\
SG & 1.67 & 2.12 & 2.89 & 2.76 & 2.74 & 2.21 \\
SSA $(\mathrm{m} 2 / \mathrm{g})$ & 2.88 & 2.91 & 5.86 & 4.76 & 5.18 & 5.73 \\
$\mathrm{D}(\mathrm{v}, 0.5)$ & 12.88 & 26.81 & 6.02 & 10.02 & 10.41 & 10.68 \\
$\mu \mathrm{m}$ & & & & & & \\
$\begin{array}{l}\% \text { retained } \\
\text { on } 45 \mu \mathrm{m}) \%\end{array}$ & 13 & 35.89 & 12.86 & 15.22 & 19.74 & 5.73 \\
\hline
\end{tabular}

There is a good distribution of the grain across the sieve sizes as shown in Figure 3. This will ensure adequate early and late strength development with the volume of $90 \%$ and $50 \%$ passing respective sieve sizes as recorded in Figure 3. With this, there is an intermediate sample sizes to help in filling the pores and for strength development.

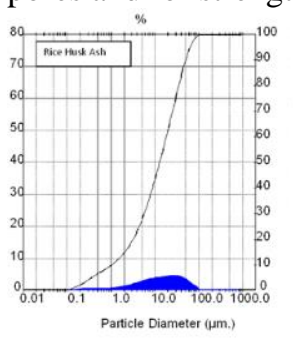

a. Rice husk ash

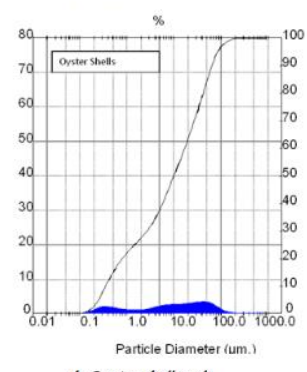

d. Oyster shells ash

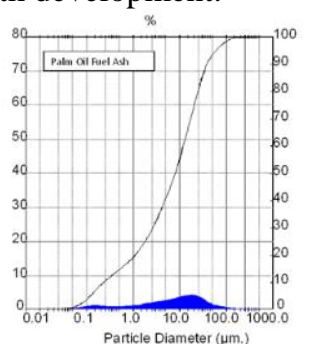

b. Palm oil fuel ash

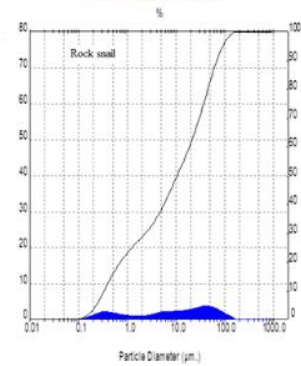

e. Rock snail ash

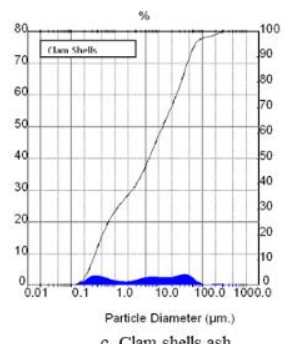

c. Clam shells ash

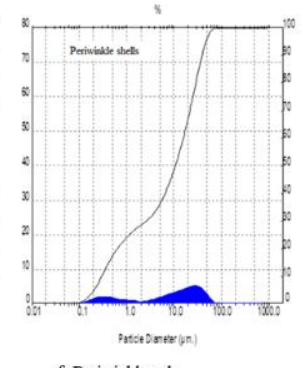

f. Periwinkle ash
Figure 3: PSD of the various agro-marine wastes.

\section{Scanning Electron Microscopy, SEM of the By-products}

In Fig. 4a, morphology for rice husk powders is revealed to be of different sizes, irregular shapes and pores are noticed on the surface. In a related study by Aprianti et al. (2015) gave account that the pores tend to absorb mixing water and thereby cause reduction in slump and workability. Earlier studied have used rice husk powders as either pozzolan in the study of Oyejobi, Abdulkadir, and Ajibola (2014) or for geopolymer concrete and mortars in Karim et al. (2013), Karim, Zain, Jamil, and Islam (2011) and Jamil et al. (2016). POFA morphology as indicated in the Figure $4 \mathrm{~b}$ consists of powders that are irregular in shapes with the presence of some spherical samples, this has tendency for micro pores as observed by Karim, Hashim, AbdulRazak, and Yusoff (2017).

Besides, morphologies for clam, oyster, rock snail and periwinkle shells in Figures 4c - f are similar in shapes, consisting of mixtures of tiny and some spherical granules. SEM with EDX in Figure 4g reveals high content of Calcium and Oxygen elements in the four shells. In (Lertwattanaruk et al., 2012), shapes of clam, oyster and cockle are observed and recorded to be irregular, multi-angle and slender which is similar to micrographs of this present study. 


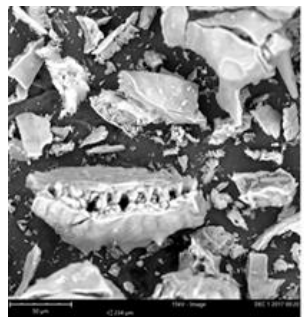

a. Rice husk ash

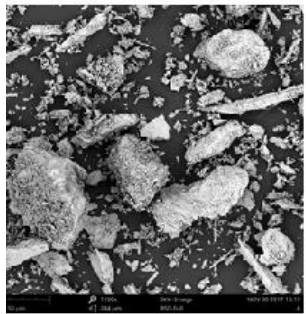

d. Oyster shell ash

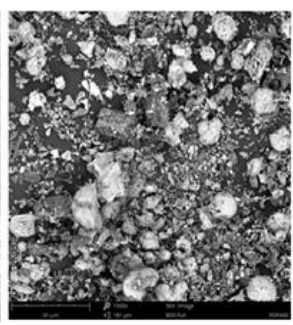

b. Palm oil fuel ash

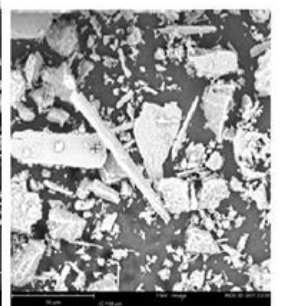

e. Rock snail shell ash

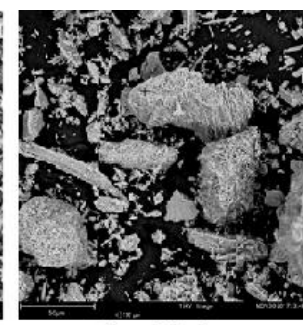

c. Clam shell ash

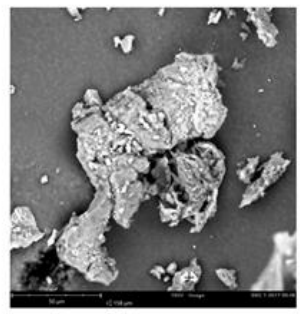

f. Periwinkle shell ash

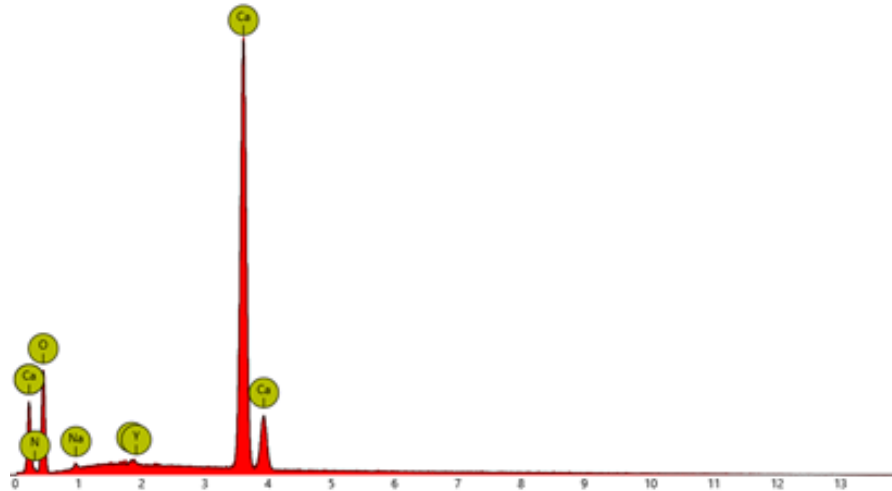

g. Calcium and Oxygen elements of marine shells by FESEM-EDX Figure 4: SEM Micrographs of the powders.

\section{X-ray Fluorescence, XRF of the ashes and powders}

Any siliceous, or siliceous and aluminous material that in itself possesses little or no cementitious value but will, in finely divided form and in the presence of water, chemically react with calcium hydroxide at ordinary temperature to form compounds possessing cementitious properties is a Pozzolana according to ASTM C618 (2003). Going by this definition and with the standard chemical composition outlined in the standard, the sum of $\left(\mathrm{SiO}_{2}+\mathrm{Al}_{2} \mathrm{O}_{3}+\mathrm{Fe}_{2} \mathrm{O}_{3}\right)$ for Treated Rice Husk Ash (TRHA) and Palm Oil Fuel Ash (POFA) are greater than minimum of 70 and $\mathrm{SO}_{3}$ is less than maximum value of 5, while sum of $\left(\mathrm{SiO}_{2}+\mathrm{Al}_{2} \mathrm{O}_{3}+\mathrm{Fe}_{2} \mathrm{O}_{3}\right)$ for Periwinkle is slightly above value of 50 , hence they can classified as Class $\mathrm{F}$ and $\mathrm{C}$ respectively. For clam, oyster and rock snail, these are neither siliceous not aluminous in nature but predominately high in Calcium oxide.

This high Calcium content of marine shells can potentially replace non-renewable limestone which is the chief source of calcium oxide in OPC that pozzolans do react with. As known, GGBFS is rich in Calcium oxide and low in silica and alumina Islam et al (2014), and Shafigh et al (2013). Despite this, its use has received wide acceptance due to the advantages which include early strength development, hence clam, oyster and rock snail which possesses high calcium content could also be used as supplementary cementitious materials provided such property is exhibited during hydration. Table 2 shows the composition and distribution of oxides in each of the waste products.

These oxides would help in calculation of cement compounds when reaction and hydration takes place. When sum of $\left(\mathrm{SiO}_{2}+\mathrm{Al}_{2} \mathrm{O}_{3}+\mathrm{Fe}_{2} \mathrm{O}_{3}\right)$ of POFA, TRHA and Periwinkle ash in Table 2 are compared with previous studies on POCP, FA, POFA and GBFS of M. Karim, H. Hashim, H. Abdul Razak, and S. Yusoff (2017), Kocak and Nas (2014), Hossein Noorvand, Ali, Demirboga, Noorvand, and Farzadnia (2013), their respective values are found to be $71.09 \%$, $75.76 \%, 58.15 \%$ and $46.83 \%$. The differences can be associated with origin of the material, burning temperature and period, grinding process among other factors. It can be concluded that identified pozzolans in this study can also be useful for better mechanical performance of concrete and mortar.

Table 2: Chemical oxides composition in each of the materials.

\begin{tabular}{ccccccc}
\hline $\begin{array}{c}\text { Compound } \\
\text { formula }\end{array}$ & Clam & Oyster & $\begin{array}{c}\text { Rock } \\
\text { Snail }\end{array}$ & $\begin{array}{c}\text { Peri- } \\
\text { Winkle }\end{array}$ & Trha & Pofa \\
\hline $\mathrm{CaO}$ & 97.46 & 95.82 & 97.03 & 38.23 & 1.19 & 4.62 \\
$\mathrm{SiO} 2$ & 0.27 & 0.62 & 0.29 & 35.54 & 92.54 & 53.52 \\
$\mathrm{~A} 2 \mathrm{O} 3$ & 0.06 & 0.30 & 0.10 & 9.53 & 0.31 & 11.40 \\
$\mathrm{Fe} 2 \mathrm{O} 3$ & 0.22 & 0.14 & 0.18 & 7.09 & 0.15 & 12.68 \\
$\mathrm{MgO}$ & 0.09 & 0.86 & 0.34 & 0.51 & 0.95 & 3.28 \\
$\mathrm{Na} 2 \mathrm{O}$ & 0.98 & 0.90 & 0.91 & 0.18 & 0.17 & 1.56 \\
$\mathrm{~K} 2 \mathrm{O}$ & 0.38 & 0.05 & 0.04 & 0.09 & 1.38 & 3.08 \\
$\mathrm{P} 2 \mathrm{O} 5$ & 0.05 & 0.19 & 0.08 & 0.01 & 2.78 & 0.18 \\
$\mathrm{SO} 3$ & 0.11 & 0.45 & 0.25 & 0.24 & 0.26 & \\
$\mathrm{Cl}$ & 0.05 & 0.29 & 0.06 & & 0.14 & \\
$\mathrm{LOI}^{\mathrm{NOI}}$ & 43 & 43.5 & 44.2 & 6.02 & 7.00 & 4.83 \\
$\left(\mathrm{SiO}_{2}\right.$ & & & & 52.16 & 93 & 77.6 \\
$+\mathrm{Al}_{2} \mathrm{O}_{3}$ & & & & & & \\
$\left.+\mathrm{Fe}_{2} \mathrm{O}_{3}\right) \%$ & & & & & & \\
\hline
\end{tabular}

\section{E. X-ray Diffraction, XRD of the ashes and powders}

The XRD pattern for the rice husk ash in Figure 5 shows Quartz, Cristobalite and Mullitte minerals. From the report generated $100 \%$ matching is recorded at 2-theta (deg) of 26.587 for quartz, 21.947 for cristobalite and 26.347 for mullitte. There are traces of oxides at other points such as $50.079,67.179,36.587,39.312$ for quartz; 31.375 and 36.056 for cristobalite, and 26.111, 33.28, 35.308 and 60.810 for Mullitte as shown in the Figures. Furthermore, the identified minerals for palm oil fuel ash include quartz, mullite and Heulandite with the compound names Silicon oxide, Aluminium silicate and Calcium Aluminium Silicate hydrate respectively. As seen from Fig. 6, 100\% matching is found at 2-theta (deg) for quartz, mullite and Heulandite at 26.587, 26.033 and 21.874 respectively. Presence of the oxides at other locations are 20.885, 50.79 and 67.86 for quartz, 42.618, $16.372,33.28,35.165$ and 60.899 for mullite and 9.658, 29.356 and 19.029 for Heulandite respectively. 

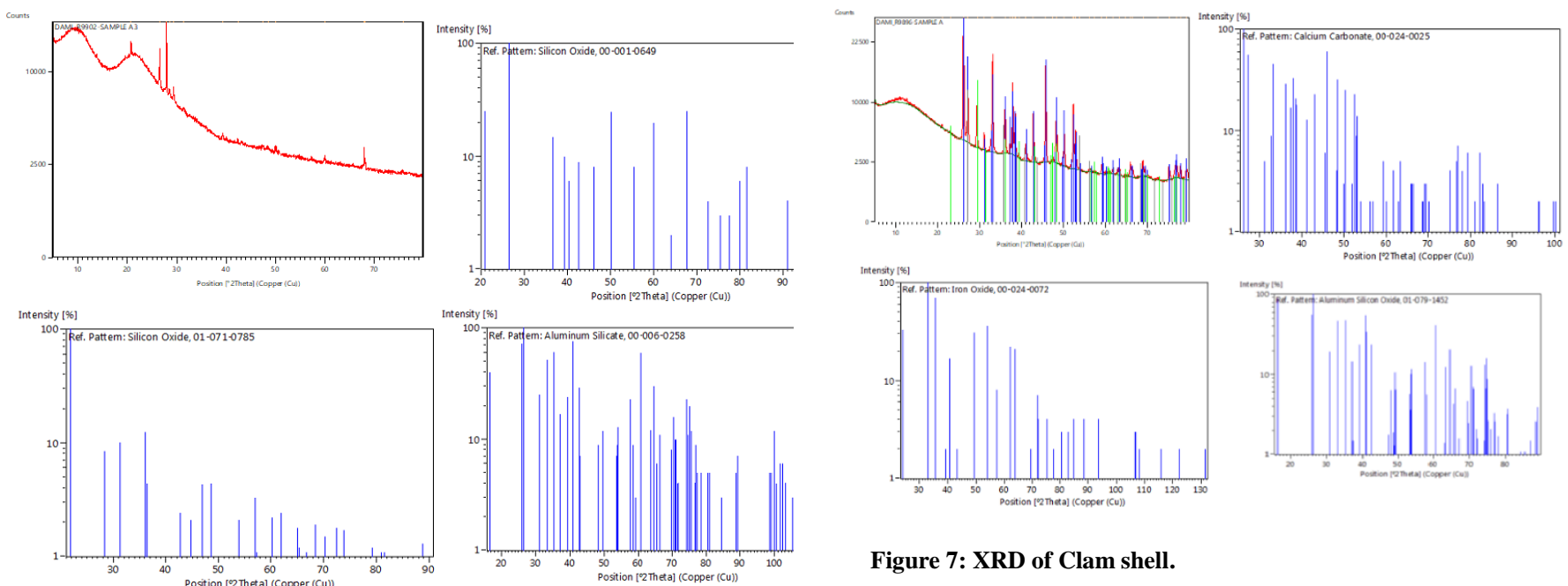

Figure 5: RHA XRD.
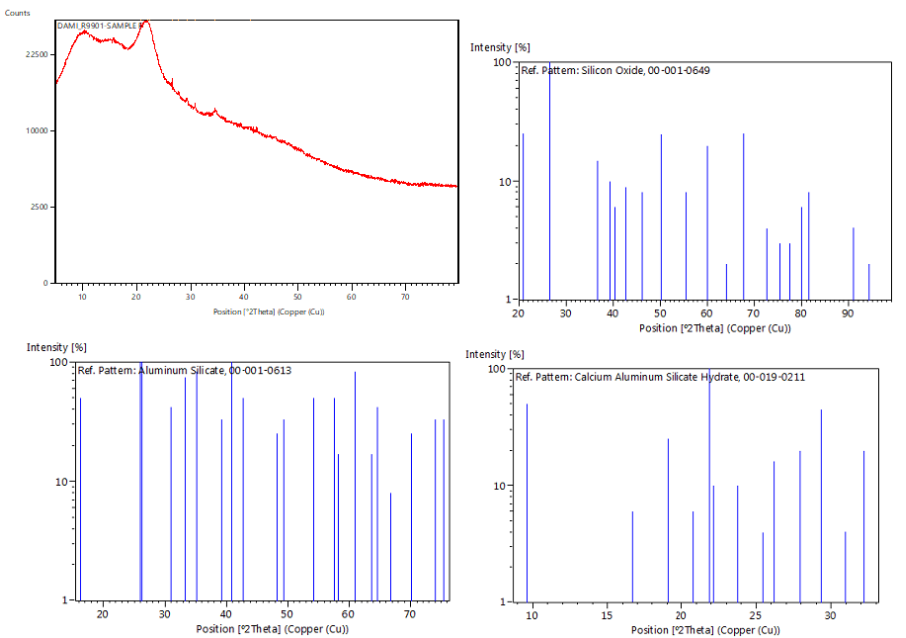

Figure 6: XRD POFA.

For clam shell powder shown in the Figure 7, the identified minerals are Aragonite (Calcium carbonate), Hematite (Iron oxide), Mullite (Aluminium Silicon oxide) and Lime (Calcium oxide). At 2-theta (deg), there is $100 \%$ matching at 26.221 , 33.11526 .153 , and 37.361 respectively for Aragonite, Hematite, Mullite and Lime minerals. Other traces of the minerals at lower matching occurred at 45.866, 27.224 and 33.153 for Aragonite, 35.612, 54.005 for Hematite, 16.4 and 25.978 for Mullite and 32.197 and 53.854 for Lime as well.

In the Figure 8 for Oyster shell powder, the present minerals are Aragonite (bleached), Calcite (Calcium carbonate), Hematite (Iron oxide), Quartz (Silicon oxide) and Mullite (Aluminium Silicon oxide). Again, at 2theta (deg), $100 \%$ matching for the content is found at 26.187, 29.395, $33.115,26.185$ and 26.192 for each of the above minerals in sequence. At some other points, the minerals are present at reduced contents which include 27.221, 45.814, 33.086 for Aragonite; 48.495 for Calcite; 35.612 and 54.005 for Hematite; 49.273 for Quartz; and 25.972, 16.410 and 40.831 for Mullite respectively.
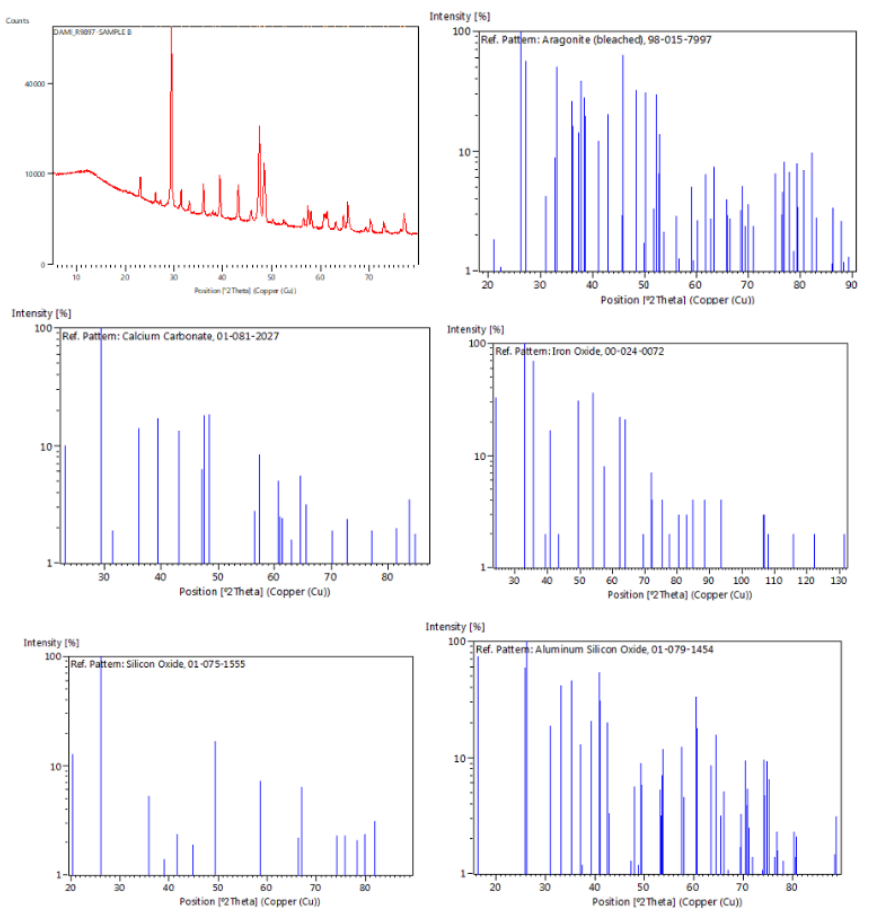

Figure 8: XRD of Oyster shell powder.

Similarly, Figure 9 shows the XRD for rock snail with Aragonite (bleached), Calcium carbonate, Hematite (Iron oxide), Mullite (Aluminium silicate oxide) and Quartz low identified as the present minerals. For 100\% at 2-theta (deg), records are at 26.187, 29.369, 33.146, 26.268 and 26.067 for the identified minerals. The minerals are also present at some other points such as at 27.221, 33.086, 45.814 for Aragonite; 48.452 and 47.450 for Calcium carbonate; $35.598,54.044$ and 24.133 for Hematite; 26.033, 40.991 and 16.464 for Mullite and 49.024 and 20.383 for quartz low.

For the Periwinkle shell powder, the identified minerals are Aragonite (Calcium carbonate), Hematite (Iron oxide) and Quartz (Silicon oxide). The values are 26.189 for Calcium carbonate, 33.28 for Iron oxide and 26.195 for Silicon oxide at 2-theta (deg). Other points where minerals are present include 
45.79, 33.153 and 48.376 for Calcium carbonate, 54.233, $35.744,49.555$ for Iron oxide and 20.453 and 49.290 for Silicon oxide respectively.
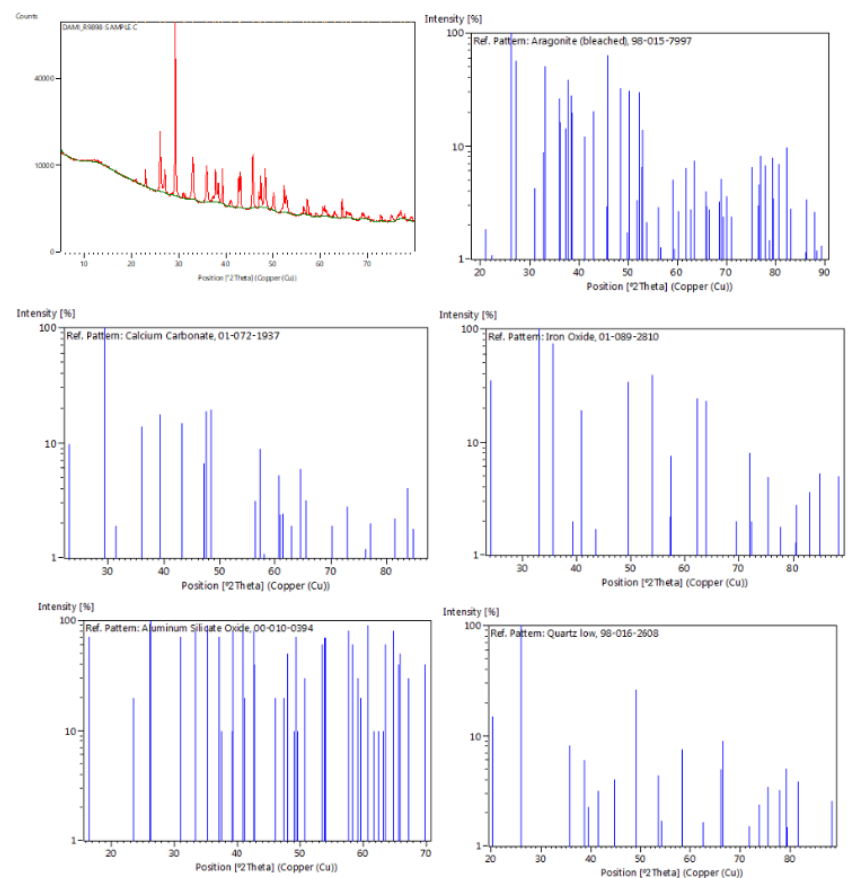

Figure 9: XRD of Rock.

\section{CONCLUSION}

Agricultural and marine by-products were harvested, pretreated and characterized in this study. The following submissions made on the material properties were as follows:

1. Fineness property of the materials was found to be within limit set out by standard except for POFA which was slightly above the value.

2. Values of specific surface area were found to be of similar values to other known pozzolanic materials with good distribution of particle sizes.

3. The material morphologies of the by-products were observed to be of irregular shapes and of different sizes.

4. The analysis results confirmed the class of RHA to be of Class F while POFA and Periwinkle were found to be Class $\mathrm{C}$ having satisfied minimum conditions of 70 and 50 for the sum of silica oxide, aluminum oxide and iron oxide respectively.

5. Marine shells of clam, oyster and rock snail were neither siliceous nor aluminous in nature but found to be Calcium-oxide dominated, this could be used as alternative materials to non-renewable limestone.

From the characterization, it was deduced that agricultural and marine by-products have physical, chemical and microstructural properties that were similar to other known pozzolanas and if harvested and harnessed properly, they could also be used in the same regard.

\section{ACKNOWLEDGMENTS}

The authors would like to appreciate University of Malaya for allowing the use of equipment for microstructures characterization.

\section{REFERENCES}

Abalaka, A. E. (2013). Strength Development and Durability Properties of Concrete Containing Pre-Soaked Rice Husk Ash. Construction Science, 14, 4-12.

Agbenyeku, E. and Aneke, I. (2014). Blended Rice Husk Ash Concrete; A Marginal Green Construction Material from Extended Hydration International Journal of Scientific and Engineering Research, 5(1), 906 -910, International Journal of Scientific \& Engineering Research, http://www.ijser.org

Aprianti, E., P. Shafigh, S. Bahri, and J.N. Farahani. (2015). Supplementary cementitious materials origin from agricultural wastes - A review. Construction and Building Materials, 74, 176-187. doi: http://dx.doi.org/10.1016/j.conbuildmat.2014.10.010

ASTM C618. (2003). Standard specification for fly ash and raw or calcined natural pozzolan for use as a mineral Admixture in Portland Cement Concrete. West Conshohocken, PA: ASTM.

ASTM C. (2003). 618. Standard specification for fly ash and raw or calcined natural pozzolan for use as a mineral Admixture in Portland Cement Concrete.

Ayininuola, G. M. and O. I. Olaosebikan. (2013). Influence of Rice husk ash on soil permeability. Transnational Journal of Science and Technology, 3(10), 29-33.

Bai, Y., F. Darcy and P. Basheer. (2005). Strength and drying shrinkage properties of concrete containing furnace bottom ash as fine aggregate. Construction and Building Materials, 19(9), 691-697.

Bakar, B. H. A., R. Putrajaya and H. Abdulaziz. (2010). Malaysian rice husk ash-improving the durability and corrosion resistance of concrete: pre-review. Concrete Research Letters, 1(1), 6-13.

Barbachi, M., A. Imad, F. Jeffali, K. Boudjellal and M. Bouabaz (2017). Physical characterization of sea shell for a concrete formulation. Journal of materials and Environmental Sciences, 8(1), 332-337.

Basha, E. A., R. Hashim, H.B. Mahmud and A.S. Muntohar. (2005). Stabilization of residual soil with rice husk ash and cement. Construction and Building Materials, 19(6), 448-453.

doi: http://dx.doi.org/10.1016/j.conbuildmat.2004.08.001

Chindaprasirt, P. and S. Rukzon. (2008). Strength, porosity and corrosion resistance of ternary blend Portland cement, rice husk ash and fly ash mortar. Construction and Building Materials, 22(8), 1601-1606.

Ettu, L., C. Ajoku, K. Nwachukwu, C. Awodiji and U. Eziefula. (2013). Strength variation of OPC-rice husk ash composites with percentage rice husk ash. International Journal of Applied Science and Engineering Research, 2(4), 420-424.

Foong, K. Y., U. J. Alengaram, M. Z. Jumaat and K.H. Mo. (2015). Enhancement of the mechanical properties of 
lightweight oil palm shell concrete using rice husk ash and manufactured sand. Journal of Zhejiang University-SCIENCE A, 16(1), 59-69.

Givi, A. N., S.A. Rashid, F. N. A. Aziz and M. A. M. Salleh (2010). Assessment of the effects of rice husk ash particle size on strength, water permeability and workability of binary blended concrete. Construction and Building Materials, 24(11), 21452150. doi: http://dx.doi.org/10.1016/j.conbuildmat.2010.04.045

Hanjitsuwan, S., T. Phoo-ngernkham, and N. Damrongwiriyanupap. (2017). Comparative study using Portland cement and calcium carbide residue as a promoter in bottom ash geopolymer mortar. Construction and Building Materials, 133, 128-134.

Hesami, S., S. Ahmadi, and M. Nematzadeh. (2014). Effects of rice husk ash and fiber on mechanical properties of pervious concrete pavement. Construction and Building Materials, 53, 680691.

Islam, A., U. J. Alengaram, M.Z. Jumaat, and I. I. Bashar (2014). The development of compressive strength of ground granulated blast furnace slag-palm oil fuel ash-fly ash based geopolymer mortar. Materials \& Design (1980-2015), 56, 833841. doi: http://dx.doi.org/10.1016/j.matdes.2013.11.080

Jamil, M., M. Khan, M. Karim, A. Kaish, and M. Zain. (2016). Physical and chemical contributions of Rice Husk Ash on the properties of mortar. Construction and Building Materials, 128, 185-198.

Karim, M., H. Hashim, H. Abdul Razak, and S. Yusoff. (2017). Characterization of palm oil clinker powder for utilization in cement-based applications. Construction and Building Materials, $135, \quad 21-29$ doi: http://dx.doi.org/10.1016/j.conbuildmat.2016.12.158

Karim, M., M. F. M. Zain, M. Jamil, and F. Lai. (2013). Fabrication of a non-cement binder using slag, palm oil fuel ash and rice husk ash with sodium hydroxide. Construction and Building Materials, 49, 894-902.

Karim, M. R., H. Hashim, H. Abdul Razak, and S. Yusoff. (2017). Characterization of palm oil clinker powder for utilization in cement-based applications. Construction and Building Materials, 135, 21-29. doi: http://dx.doi.org/10.1016/j.conbuildmat.2016.12.158

Karim, M. R., M. F. Zain, M. Jamil, and M.N. Islam. (2011). Strength of concrete as influenced by palm oil fuel ash. Australian Journal of Basic and Applied Sciences, 5(5), 990-997.

Kocak, Y. and S. Nas. (2014). The effect of using fly ash on the strength and hydration characteristics of blended cements. Construction and Building Materials, 73, 25-32.

Lertwattanaruk, P., N. Makul and C. Siripattarapravat. (2012). Utilization of ground waste seashells in cement mortars for masonry and plastering. Journal of environmental management, 111, 133-141.

Lin, K., W. Chang, and D. Lin. (2008). Pozzolanic characteristics of pulverized incinerator bottom ash slag. Construction and Building Materials, 22(3), 324-329.

Marto, A., K. A. Kassim, A. M. Makhtar, L. F. Wei and Y. S. Lim. (2010). Engineering characteristics of Tanjung Bin coal ash. Electronic Journal of Geotechnical Engineering, 15, 11171129.

Muthusamy, K. and N. Sabri. (2012). Cockle shell: a potential partial coarse aggregate replacement in concrete.
International Journal of Science, Environment and Technology, 1(4), 260-267.

Naganathan, S., A. Y. O. Mohamed, and K. N. Mustapha. (2015). Performance of bricks made using fly ash and bottom ash. Construction and Building Materials, 96, 576580 .

Naganathan, S., N. Subramaniam and K. N. B. Mustapha. (2012). Development of brick using thermal power plant bottom ash and fly ash. Asian Journal of Civil Engineering, 13(2), 275-287.

Noorvand, H., A. A. Ali, R. Demirboga, N. Farzadnia, and H. Noorvand. (2013). Incorporation of nano $\mathrm{TiO} 2$ in black rice husk ash mortars. Construction and Building Materials, 47, 1350-1361. doi: http://dx.doi.org/10.1016/j.conbuildmat.2013.06.066

Noorvand, H., A. A. Ali, R. Demirboga, H. Noorvand and N. Farzadnia. (2013). Physical and chemical characteristics of unground palm oil fuel ash cement mortars with nanosilica. Construction and Building Materials, 48, 1104-1113.

Ogork, E.-N. N. and O. A. Uche. (2014). Performance of groundnut husk ash (GHA)-rice husk ash (RHA) modified concrete in acidic environment. International Journal of Engineering Research and Applications, 4(11), 71-77.

Okafor, F. O. and U. N. Okonkwo (2009). Effects of rice husk ash on some geotechnical properties of lateritic soil. Nigerian Journal of Technology, 28(1), 46-52.

Olivia, M. and R. Oktaviani. (2017). Properties of Concrete Containing Ground Waste Cockle and Clam Seashells. Procedia engineering, 171, 658-663.

Opeyemi, D. and O. Makinde. (2012). The suitability of partial replacement of cement with rice husk ash and bone powder in concrete structures. International journal of emerging technology and advanced engineering, 2(9), 261265.

Othman, N. H., B. H. A. Bakar, M. Don and M. Johari (2013). Cockle shell ash replacement for cement and filler in concrete. Malaysian Journal of Civil Engineering, 25, 201-211.

Oyejobi, D. O., T. S. Abdulkadir and V. M. Ajibola. (2014). Investigation of rice husk ash cementitious constituent in concrete. International Journal of Agricultural Technology, 10(3), 533-542.

PIND. (2011). Palm Oil Value Chain Analysis in the Niger Delta. 1st Floor St. Ja mes Building, 167 Ademola Adetokunbo Crescent, Wuse II, Abuja, Nigeria.

Ponnada, M. R., S. S. Prasad and H. Dharmala. (2016). Compressive strength of concrete with partial replacement of aggregates with granite powder and cockle shell. Mal. J. Civ. Eng, 28(2), 183-204.

Pyo, S. and H. K. Kim. (2017). Fresh and hardened properties of ultra-high performance concrete incorporating coal bottom ash and slag powder. Construction and Building Materials, 131, 459-466.

Rahman, M., A. Muntohar, V. Pakrashi, B. Nagaratnam and D. Sujan. (2014). Self compacting concrete from uncontrolled burning of rice husk and blended fine aggregate. Materials \& Design, 55, 410-415.

Ranjbar, N., M. Mehrali, A. Behnia, U. J. Alengaram and M. Z. Jumaat. (2014). Compressive strength and 
microstructural analysis of fly ash/palm oil fuel ash based geopolymer mortar. Materials \& Design, 59, 532-539. doi: http://dx.doi.org/10.1016/j.matdes.2014.03.037

Salih, M. A., N. Farzadnia, A. A. Ali and R. Demirboga. (2015). Development of high strength alkali activated binder using palm oil fuel ash and GGBS at ambient temperature. Construction and Building Materials, 93, 289-300. doi: http://dx.doi.org/10.1016/j.conbuildmat.2015.05.119

Shafigh, P., M. Z. Jumaat, H. B. Mahmud and U.J. Alengaram. (2013). Oil palm shell lightweight concrete containing high volume ground granulated blast furnace slag. Construction and Building Materials, 40, 231-238. doi: http://dx.doi.org/10.1016/j.conbuildmat.2012.10.007

Siddique, R., P. Aggarwal, P. and Y. Aggarwal. (2012). Influence of water/powder ratio on strength properties of selfcompacting concrete containing coal fly ash and bottom ash. Construction and Building Materials, 29, 73-81.

Singh, M. and R. Siddique. (2014). Strength properties and micro-structural properties of concrete containing coal bottom ash as partial replacement of fine aggregate. Construction and Building Materials, 50, 246-256.
Slavik, R., V. Bednarik, M. Vondruska, M. and A. Nemec. (2008). Preparation of geopolymer from fluidized bed combustion bottom ash. Journal of Materials Processing Technology, 200(1-3), 265-270.

Tsado, T., M. Yewa, S. Yaman and F. Yewa. (2014). Comparative analysis of properties of some artificial pozzolana in concrete production. International Journal of Engineering and Technology, 4(5), 251-255.

Umoh, A. and K. Olusola. (2013). Performance of periwinkle shell ash blended cement concrete exposed to magnesium sulphate. Civil Engineering Dimension, 15(2), 96101.

Zain, M. F. M., M. N. Islam, F. Mahmud and M. Jamil. (2011). Production of rice husk ash for use in concrete as a supplementary cementitious material. Construction and Building Materials, 25(2), 798-805. doi: http://dx.doi.org/10.1016/j.conbuildmat.2010.07.003 